\title{
NACA 4412 Kanadı Üzerinde Bir Emme Kanalı Tasarlanmasının Aerodinamik Etkileri
}

\author{
Tuğrul Oktay ${ }^{1}$ ve Öztürk Özdemir Kanat ${ }^{2^{*}}$ \\ ${ }^{1}$ Erciyes Üniversitesi, Havacılık ve Uzay Bilimleri Fakültesi, Uçak Mühendisliği Bölümü, Kayseri, Türkiye (ORCID: 0000000348602230 ) \\ ${ }^{2}$ Kastamonu Üniversitesi, Sivil Havacılık Yüksekokulu, Uçak Gövde-Motor Bakım Bölümü, Kastamonu, Türkiye (ORCID: 0000-0001-7914-0871)
}

(İlk Geliş Tarihi 16 Kasım 2019 ve Kabul Tarihi 19 Aralık 2019)

(DOI: $10.31590 /$ ejosat.651523)

ATIF/REFERENCE: Oktay, T. \& Kanat, Ö. Ö. (2019). NACA 4412 Kanadı Üzerinde Bir Emme Kanalı Tasarlanmasının Aerodinamik Etkileri. Avrupa Bilim ve Teknoloji Dergisi, (17), 1001-1007.

\begin{abstract}
Öz
Bu çalışmada NACA 4412 profili kullanılarak bir kanat tasarlanmış ve suction yöntemi ile hesaplamalı sayısal analizi tartışılmıştır. Öncelikle 3 boyutlu kanat SolidWorks programı ile tasarlanmış ve tasarlanan bu kanadın sayısal analizi bir hesaplamalı akışkanlar dinamiği programı olan Ansys Fluent kullanılarak gerçekleştirilmiştir. Sayısal analiz için iki farklı konfigürasyon belirlenmiştir. Bu konfigürasyonlardan ilki olan $S_{I}$ kanadın yalın halini yani suction olmayan halini ifade ederken; $S_{2}$ suction kanalına sahip olan kanat tasarımını ifade etmektedir. Oluşturulan kanadın düz uçuşunu 6 derece hücum açısı ile gerçekleştirdiğine karar verilmiş ve bu hücum açısında kanat üzerindeki akış ayrılmalarının kanat chord uzunluğunun \%25' inde meydana geldiği yapılan sayısal analizle tespit edilmiştir. Chord uzunluğunun bu noktasından kanat üst yüzeyinden başlayıp iç kısmından devam eden son olarakta firar kenarından hava ile buluşan bir venturi kanal oluşturulmuştur. Bu kanalın temel amacı uçuş esnasında akışın bozulmaya başladığı yerde kuvvet azaltımı yapılarak aerodinamik performans artışının sağlanabilmesidir. Aerodinamik performanstaki değişimin incelenebilmesi için kanat üzerinde meydana gelen taşıma ve sürükleme katsayısı değerleri her iki konfigürasyon içinde 10 farklı hücum açısında (i.e. -6,-4, $-2,0,2,4,6,8,10,12)$ ayrı ayrı olacak şekilde elde edilmiştir. $S_{1}$ ve $S_{2}$ konfigürasyonları için elde edilen bu katsayı değerleri birbirleri ile karşılaştırılmıştır. Karşılaştırılan sonuçlara göre, yapılan bu sayısal analiz çalışmasında $S_{1}$ konfigürasyonuna göre $S_{2}$ konfigürasyonunun performansında belirgin bir artış olduğu tespit edilmiştir.
\end{abstract}

\section{Aerodynamic Effects of Designing A Suction Channel Over NACA 4412 Wing}

\begin{abstract}
In this study, a wing is designed by using NACA 4412 profile and computational numerical analysis is discussed with suction method. First of all, the 3D wing is designed with the SolidWorks and the numerical study of this designed wing is carried out using ANSYS Fluent, a famous CFD (i.e. Computational Fluid Dynamics) software. It is based upon finite volume method approach. Two different configurations are used for numerical study. The first of these configurations is the $S_{1}$, which represents the initial state of the wing; $S_{2}$ refers to the wing design with suction channel. The straight flight angle of attack of the wing is 6 degree and the flow separations over the wing, which occurred in $25 \%$ of the wing chord length, are calculated at this angle of attack by the numerical study. At this point of chord length, a venturi channel is formed which initial point is the upper surface of the wing and throughout the inner part and finally meets with air from the trailing edge. The main purpose of this channel is to decrease the force at the place where the flow begins to deteriorate during the flight and to increase the aerodynamic performance. In order to be able to examine the change in aerodynamic
\end{abstract}

\footnotetext{
* Sorumlu Yazar: Kastamonu Üniversitesi, Sivil Havacılık Yüksekokulu, Uçak Gövde-Motor Bakım Bölümü, Kastamonu, Türkiye, ORCID: 00000001-7914-0871, ozturkkanat@gmail.com
} 
performance, the lift and drag coefficient values on the wing are obtained in 10 angles of attack (i.e. -6, -4, -2, 0, 2, 4, 6, 8, 10, 12) separately for both configurations. These coefficients obtained for $S_{1}$ and $S_{2}$ configurations are compared with each other. In this numerical study based on the comparison results, it is found that there is a significant increase in the performance of $S_{2}$ configuration compared to the $S_{l}$ configuration.

Keywords: Active flow Control, Suction Method, Maximum Fineness

\section{Introduction}

UAVs (i.e. Unmanned aerial vehicles) continue to take place increasingly in many areas of life, both commercial and daily, for hobby purposes and because of military needs. In short, UAVs have great importance in meeting the needs in many different areas such as our daily needs (Austin, 2010 and Arik et al., 2018). Therefore, studies related to UAVs were examined and a literature review was carried out. As a result of the literature review, it is seen that the majority of the studies are aimed at increasing the efficiency of UAVs (Konar, 2019). Starting from here, a wing was designed using the NACA 4412 profile, which could be the wing of a UAV. The lift $\left(\mathrm{C}_{\mathrm{L}}\right)$ and drag $\left(\mathrm{C}_{\mathrm{D}}\right)$ coefficients of this designed wing were calculated numerically. The ANSYS Fluent program, which works according to the finite volume method, was used for numerical computation. ANSYS Fluent is known as a computational fluid dynamics program. Especially in the last quarter century, in parallel with the developments in computer technology and intensive studies on CFD calculations, CFD has become more easily applicable and a very good alternative to experimental studies. Jansson et al. (Jansson et al., 2012) using CFD method simulated NACA 0012 profile with finite volüme method.

Flow control is described as changing the direction of a fluid to increase the flow efficiency. Today, active flow control technique is used to reduce problems such as excessive fuel consumption and high noise which constitute a negative situation for air vehicles (Burnazzi \& Radespiel, 2015). Prandtl (Prandtl, 1927) stated that it can provide benefits by controlling the flow around an object. In the following years, various flow control techniques were carried out to improve wing aerodynamic performance. In addition to the aim of increasing the aerodynamic performance of the wing, it is also aimed to increase the controllability of air vehicles through the active flow control method. Despite the recent advances in this technology, the application of active systems to an aircraft is a fundamental problem. In this study, the difficulties of using external sources for flow control and possible negative effects were taken into consideration and the design changes were made to guide the flow. In this study, the suction method, one of the flow control methods, was used (Azim et al., 2015).

Control systems applied as constant to give direction to a flow are called passive flow control methods. The control method in which the direction and force of the fluid can be intervened at any time of the flow at any time is known as the active flow control method (Oktay \& Kanat, 2017). In the passive control method, no external energy source is needed, whereas in the active control method an external energy source is generally needed. Active control method has two important advantages over passive control method. These are: ensuring the controllability of the flow with small energy outputs and changing the energy position and amounts as required. The basic logic of the active control method is that the energy is intervened by the external energy source into the flow. In addition to these, intervention according to needs is the greatest advantage. Konar (Konar, 2019), has studied about redesign of morphing UAV's winglet to improve UAV's performance. For an aircraft, using winglet external flow can be controlled easily.

This paper presents a numerical investigation on the aerodynamic effects of designing a suction channel through the wing. For this purpose, two different wing designs were determined. The first of these is the simple form of the wing without any insertion and named as $S_{l}$ configuration. Another is the design with suction channel designed on the wing, which is called the $S_{2}$ configuration. This research article is focused on comparing the obtained $E_{\max }$ (i.e. Maximum lift/drag ratio and it refers to total aerodynamic performance) results for each configurations, and so it is aimed to increase the total aerodynamic performance.

\section{Material and Method}

\subsection{Suction Channel}

In order to achieve the best aerodynamic performance of a wing design, the pressure difference between the lower and upper surfaces of the wing must be at the highest possible value. In this study, the suction channel is designed to start from $1 / 4$ of the length of the wing cord, from the wing leading edge of the wing upper surface. The main reason why the inlet of the suction channel is initiated from this zone is that the wing straight flight angle is considered to be 6 degree angle of attack and this is due to the starting point of flow separation on the upper surface of the wing at the angle of attack.

Increasing the dynamic pressure of the air entering the wing by means of the suction channel is aimed to rapidly leave the wing from the trailing edge. For this reason, the channel is designed as a venturi. The main purpose of designing the intake channel is that air reaching high speed on the wing cannot follow the airfoil profile. As a result of this situation, drag increases and lift decreases. Figure 1 shows the airfoil and suction channel. 


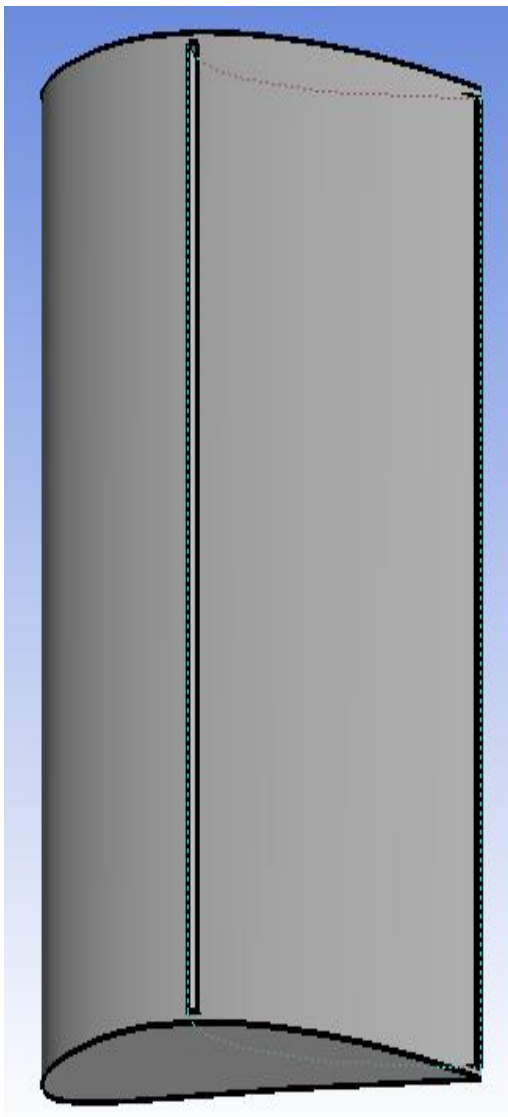

$a$

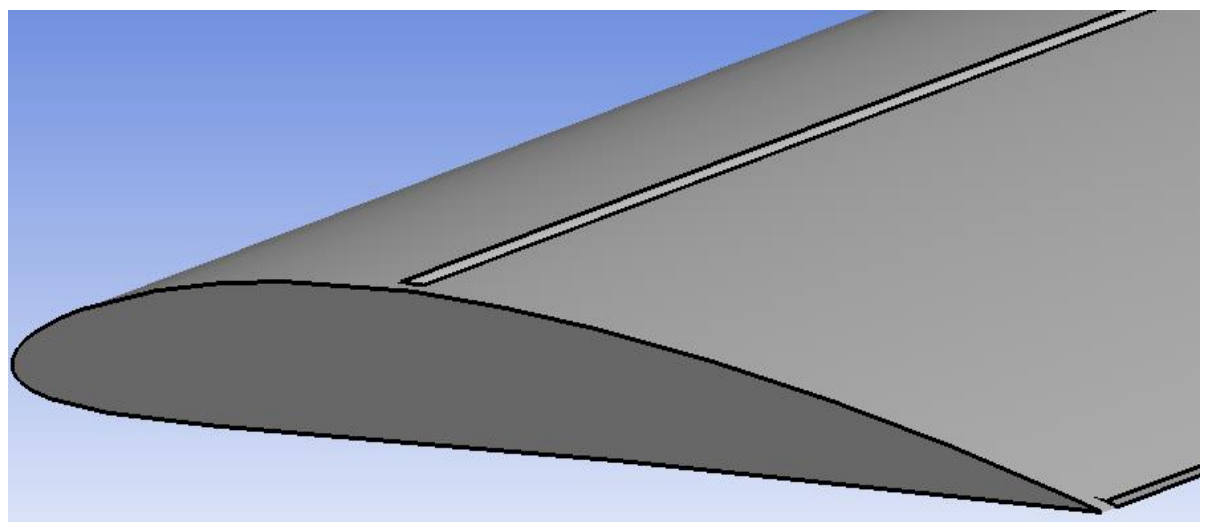

$b$

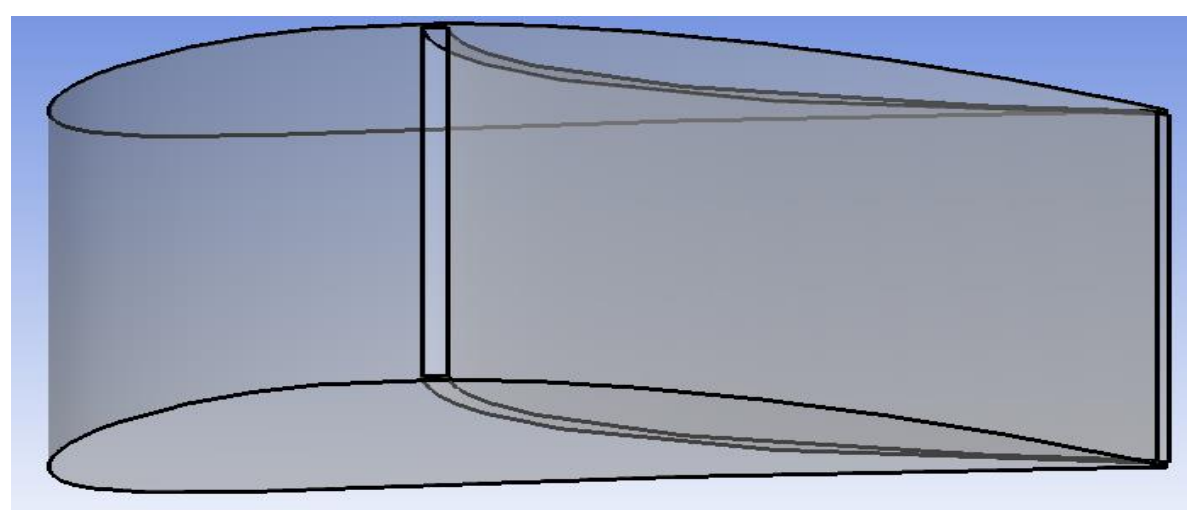

$c$

Figure 1. Different Views of Wing With Suction Channel

\subsection{Numerical Study}

After the three-dimensional geometry was created, the boundary was divided into control volumes and the wing performance was calculated. This control volume generation operation was carried out separately for $S_{1}$ and $S_{2}$ configurations. For the numerical study, the number of cells has been preferred in order to obtain the most accurate results in the shortest time. The cells used are shown in Figure 2. In order to make an accurate comparison, the first element heights, maximum element sizes and growth rates were tried to be equal for both configurations (Kanat et al., 2017).

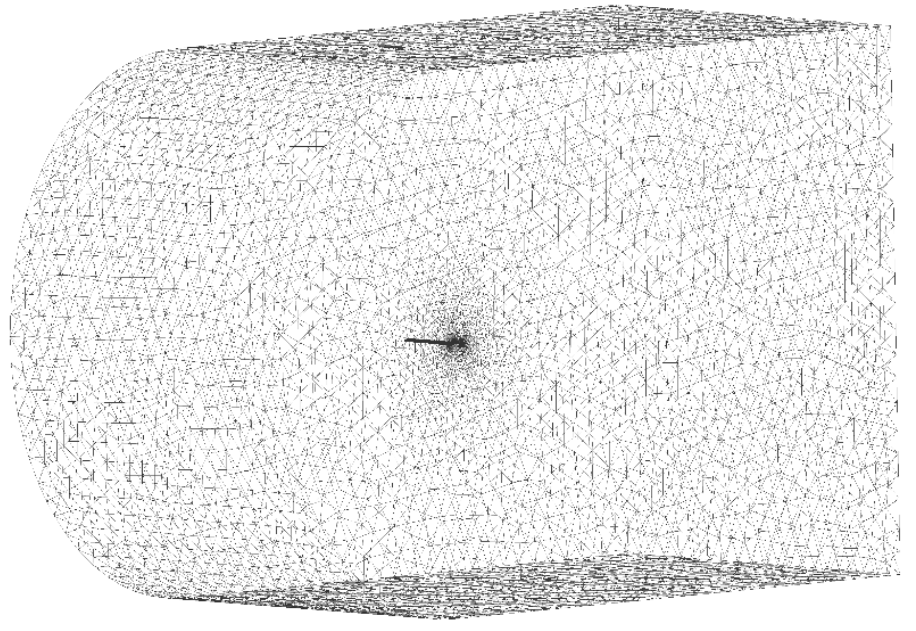




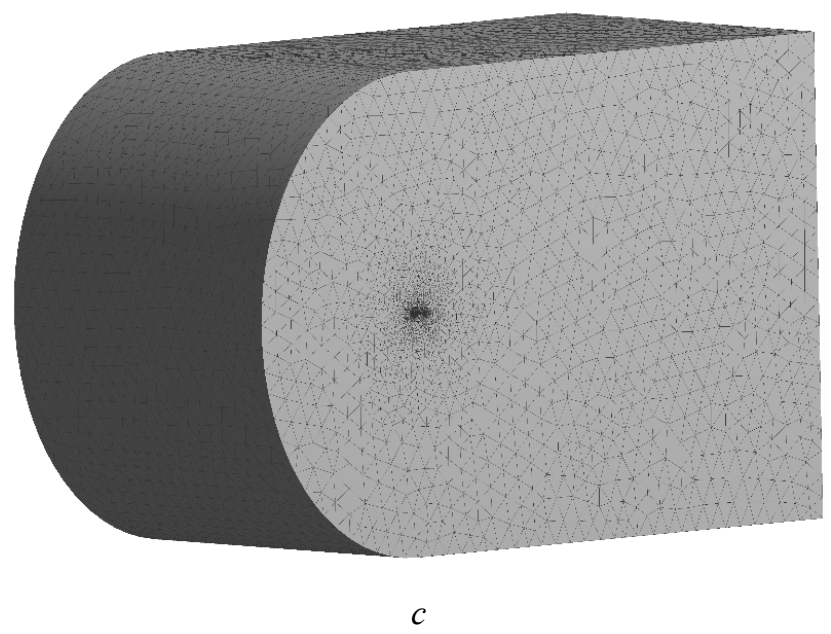

Figure 2. a. Boundary b. Wireframe c. Control Volume

After cells were formed, fluid properties and turbulence model were determined (Nichols, 2010) Then, the wing top view area is defined as the reference area in order to calculate wing lift and drag coefficient values. After determining the sufficient number of iterations by the solution method, aerodynamic coefficient calculations were made for the different angle of attack for each configuration. $E_{\max }$ was calculated according to the obtained $C_{L}$ and $C_{D}$ values and the change in total aerodynamic performance was evaluated.

\section{Results and Discussion}

\subsection{Lift Coefficient $\left(C_{L}\right)$ and Drag Coefficient $\left(C_{D}\right)$}

Figure 3 shows the lift coefficient. For the $S_{l}$ and $S_{2}$ configurations, separately calculated $C_{L}$ values are shown. Due to the NACA 4412 profile structure, it is seen that a lift occurs in the -2 and -3 degrees angles of attack, there is little if any small values. When the angle of attack increases with the $S_{2}$ configuration compared to $S_{1}$, it appears that the suction channel has a negative effect on lift. For the angle of attack of 2 degrees, it can be said that the lift is almost equal. As the angle of attack decreases, it is understood that the suction channel affects the lift positively.

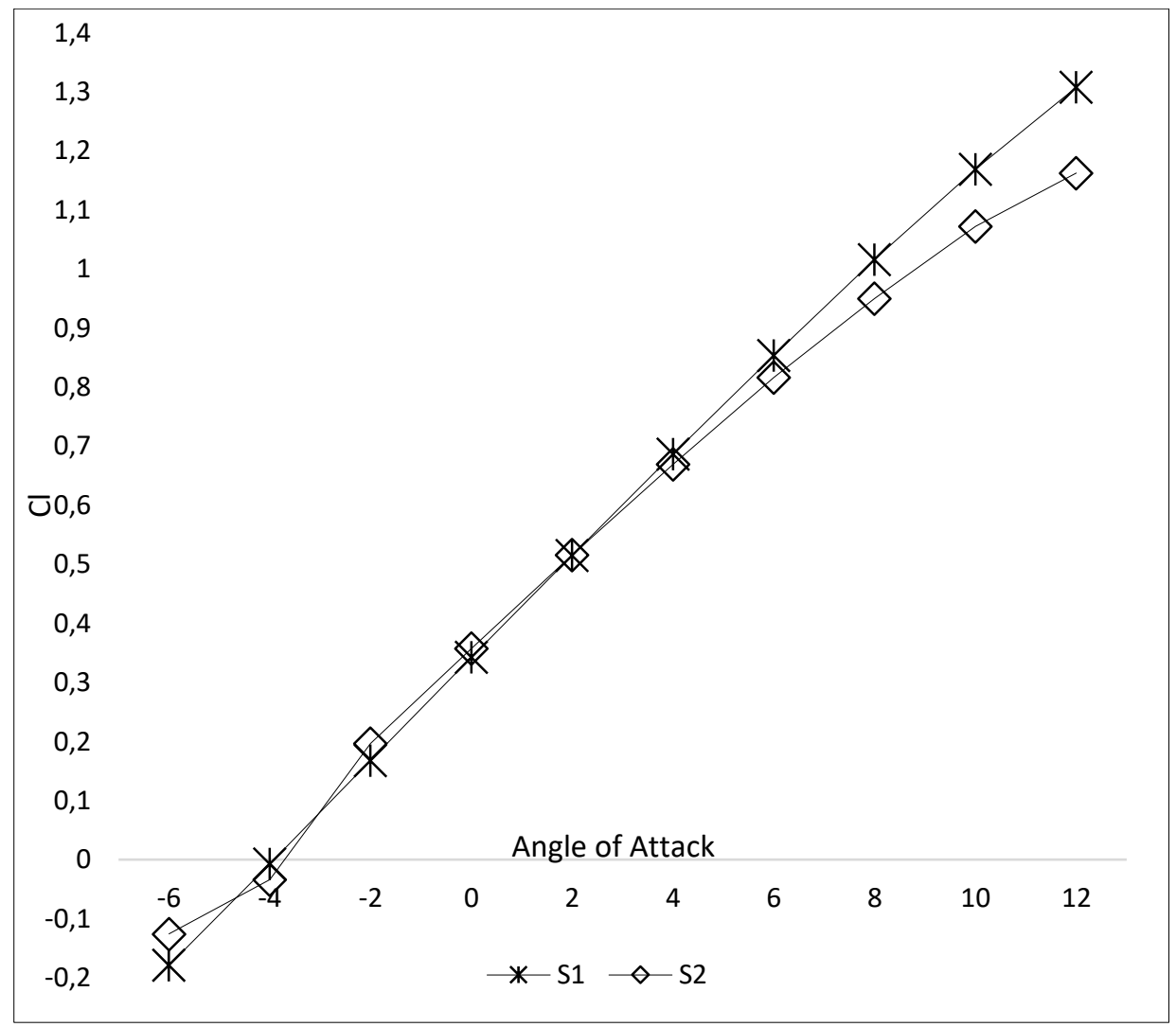

Figure 3. $C_{L}$ 
The drag coefficient obtained is shown in Figure 4. The 6 degree angle of attack appears to be the decisive factor for the $S_{1}$ and $S_{2}$ configurations' $C_{D}$ values. In terms of this angle of attack, it is seen that more drag occurs for the $S_{2}$ configuration for smaller angle of attack, whereas the positive effect on drag values is seen at larger angles of attack.

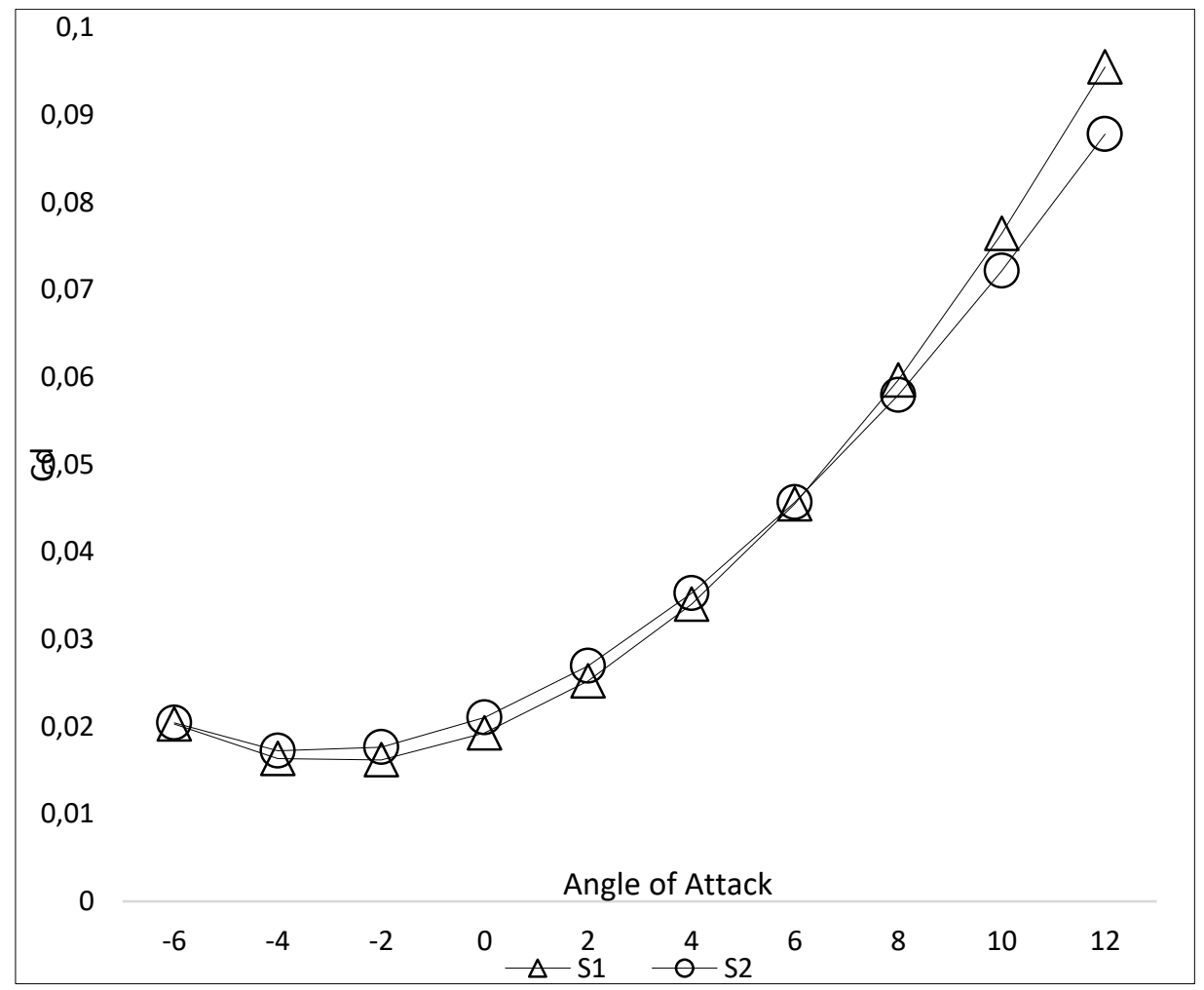

Figure 4. $C_{D}$

\section{2. $E_{\max }$ (Maximum Lift/Drag Ratio)}

$E_{\max }$ enables us to evaluate the changes in $C_{L}$ and $C_{D}$ according to the angle of attack as a common and to provide information about total performance change. $E_{\max }$ equation 1 is used to calculate the equation (Vinh, 1993).

$$
E_{\max }=1 / 2 \sqrt{k \times C_{L}^{2}}
$$

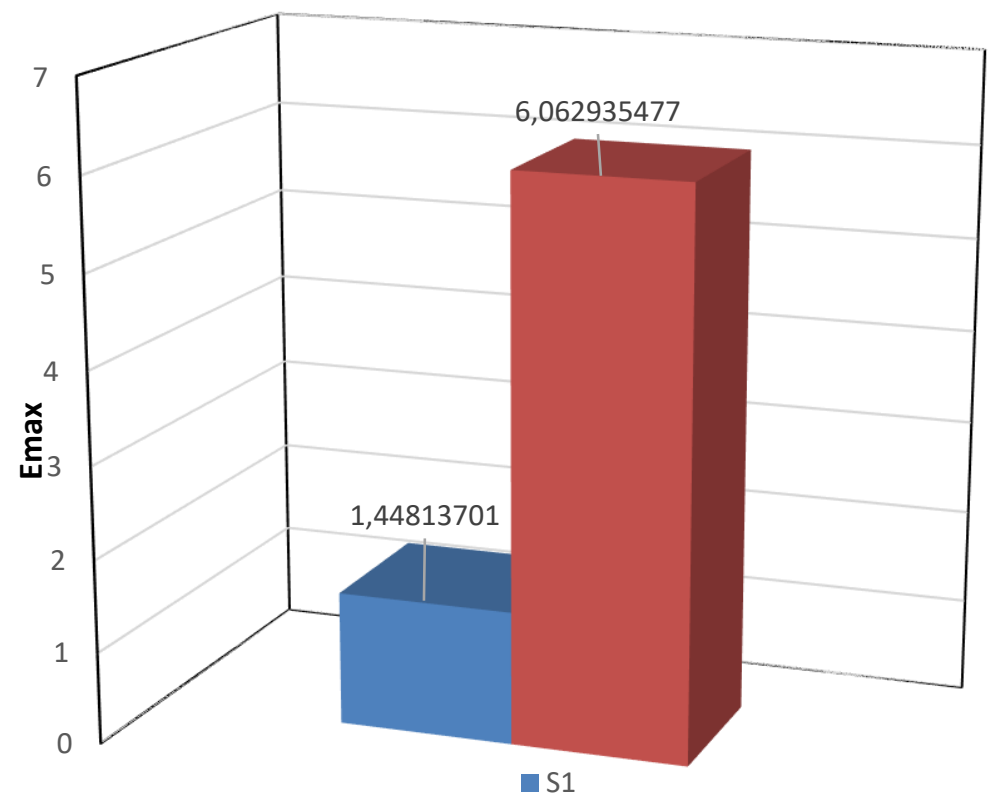

Figure 5. $E_{\max }$ 
The $E_{\max }$ values calculated according to equation 1 for $S_{l}$ and $S_{2}$ are given in Figure 5. Clearly, there is an increase in $E_{\max }$, a common assessment of $C_{L}$ and $C_{D}$ results with suction channel design.

\subsection{Turbulence Kinetic Energy}

Figure 6 shows turbulence kinetic energy (i.e. the kinetic energy per unit mass of the turbulent fluctuations in a turbulent flow ) views of $S_{1}$ and $S_{2}$ configurations at 6 degree angle of attack (URL-1). As clearly seen from this figure, turbulence kinetic energy is stable after the suction channel is created.
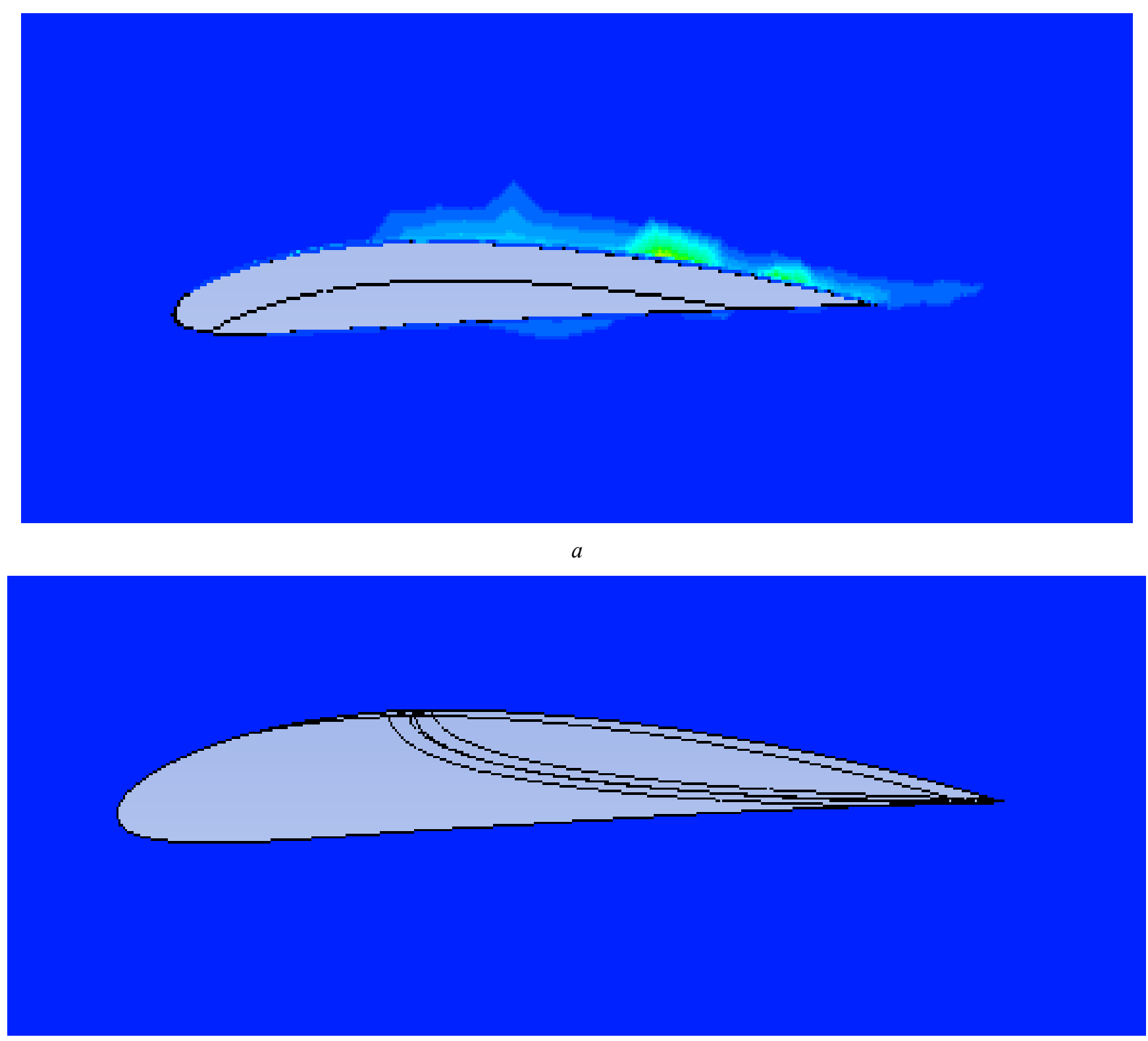

$b$

Figure 6. Turbulence Kinetic Energy For Configurations a. $S_{1}$ b. $S_{2}$

\section{Conclusion}

With this research article, a suction channel was created on a wing designed using NACA 4412 profile and flow control was tried to be provided. As the main contribution of this study to the literature, it can be evaluated that the changes in wing design can be directed to flow and as a result, total performance can be increased. In addition to this, the flow seperation on the wing can be delayed using suction channels. For further studies, higher efficiency will be obtained by designing different suction channels (i.e. size, channel inletoutlet position, channel start point, channel end point) and optimization of them. At the same time, strength calculations can be made for the wings that have suction channel. As a result, it has been shown in this study that aerodynamic performance can be significantly influenced by flow controls to be performed with aerodynamic design of aircraft. 


\section{References}

Ansys Fluent Theory Guide, 2013.

Austin, R. 2010. Unmanned aircraft systems. Wiley.

Arik, S., Turkmen, I., \& Oktay, T. (2018). Redesign of morphing UAV for simultaneous improvement of directional stability and maximum lift/drag ratio. Advances in Electrical and Computer Engineering, 18(4), 57-63.

Azim, R., Hasan, M. M., \& Ali, M. (2015). Numerical investigation on the delay of boundary layer separation by suction for NACA 4412. Procedia Engineering, 105, 329-334.

Burnazzi, M., \& Radespiel, R. (2015). Synergies between suction and blowing for active high-lift flaps. CEAS Aeronautical Journal, $6(2), 305-318$.

Jansson, J., Hoffman, J., \& Jansson, N. (2012). Simulation of 3d unsteady incompressible flow past a naca 0012 wing section.

Kanat, Ö. Ö., Körpe, D. S., \& Kurban, A. O. (2017). Yatay Kuyruklarda Kıvrık Kanat Ucu Kullanımının Aerodinamik Etkileri. Journal of Aviation, 1(2), 87-98.

Konar, M . (2019). GAO Algoritma tabanlı YSA modeliyle İHA motorunun performansının ve uçuş süresinin maksimizasyonu. Avrupa Bilim ve Teknoloji Dergisi , (15) , 360-367 . DOI: 10.31590/ejosat.529093

Konar, M. (2019). Redesign of morphing UAV's winglet using DS algorithm based ANFIS model. Aircraft Engineering and Aerospace Technology.

Nichols, R. H. (2010). Turbulence models and their application to complex flows. University of Alabama at Birmingham, Revision, 4, 89.

Oktay, T., \& Kanat, O. O. (2017, October). A review of aerodynamic active flow control. In 8th international advanced technologies symposium (IATS'17).

Prandtl, L. (1927). The generation of vortices in fluids of small viscosity. The Aeronautical Journal, 31(200), 718-741.

URL-1. https://www.cfd-online.com/Wiki/Turbulence kinetic_energy

Vinh, N. X. (1995). Flight mechanics of high-performance aircraft (Vol. 4). Cambridge University Press. 